\title{
Bark and wood-boring beetle response in red pine (Pinus resinosa Ait.) plantations damaged by the 1998 ice storm: Preliminary observations ${ }^{1}$
}

\author{
by Krista L. Ryall ${ }^{2}$ and Sandy M. Smith ${ }^{3}$
}

\section{Introduction}

In January 1998, a severe ice storm occurred across eastern Canada and the northeastern United States. While ice storms are not unknown to this region (Lemon 1961, Mahaffy 1961, Stroempl 1971), the severity, duration, and extent of this particular storm was unusual (Savage 1998). Ice accumulation of up to $80 \mathrm{~mm}$ was reported and accumulations of $30-60 \mathrm{~mm}$ were common across eastern Ontario and Quebec. This storm resulted in extensive damage to forests of the region, affecting thousands of hectares of hardwood forests and coniferous stands, including many valuable red pine (Pinus resinosa Ait.) plantations (Fig. 1) (Irland 1998).

Damage in the red pine stands (Fig. 2 and 3) ranged from light, characterized by broken leaders, to patches of severe damage, where crowns were lost (Irland 1998). Observed damage included: 1) trees with varying levels of crown loss (from $<25 \%$ to $>75 \%$ ) but with green branches remaining; 2) trees with complete crown loss having snapped along the trunk (snags); 3) uprooted trees lying on the ground with the root system exposed; 4) trees blown-down with the trunk lying on the ground but the root system still largely intact in the soil; and 5) trees with varying degrees of bend in the trunk (from slight to extreme where the crown has touched the ground). Storm damage, therefore, resulted in high volumes of downed coarse woody debris and large numbers of standing injured trees.

\section{Potential for beetle damage}

After the storm, questions arose with respect to the future of damaged pine plantations. In particular, concern was raised that additional tree mortality would be caused by opportunistic bark beetle (Scolytidae) and wood-boring beetle (Cerambycidae) populations. The ecological role of these beetles is to act as thinning agents removing weakened trees from the environment and assisting in nutrient cycling. However, under exceptional circumstances, such as those observed after the ice storm, bark beetles and wood borers can cause extensive damage to North American conifer species, resulting in physical degradation of lumber and possibly affecting adjacent healthy trees (Waters et al. 1985, Irland 1998).

Bark beetles comprise some of the most destructive forest insect pests in North America and Europe (Rudinsky 1962). Tree death is caused by large densities of colonizing beetles and their associated fungi, which damage the phloem layer (Raffa and Berryman 1983). The fungi are vectored by the adult beetles

\footnotetext{
${ }^{1}$ Paper presented at the Ice Storm 1998 Forest Research Conference, Ottawa, October 19-22, 2000.

${ }^{2}$ Faculty of Forestry, University of Toronto, Toronto, Ontario M5S 3B3. E-mail: krista.ryall@utoronto.ca

${ }^{3}$ Faculty of Forestry, University of Toronto, Toronto, Ontario M5S 3B3. E-mail: s.smith.a@utoronto.ca
}

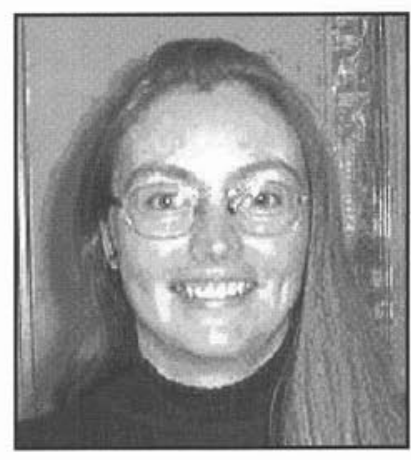

Krista L. Ryall

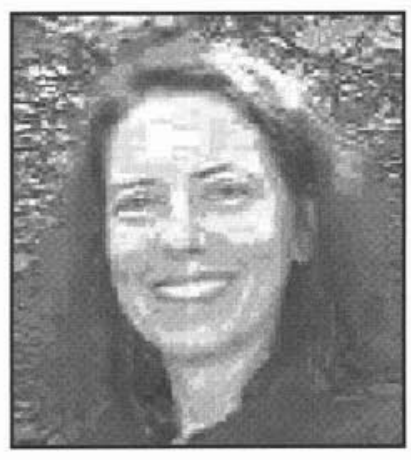

Sandy M. Smith as they bore into the wood and create galleries. The resulting wood is stained and this further reduces the value of the timber. The native pine engraver [Ips pini (Say) (Coleoptera, Scolytidae)] has caused considerable damage to plantation pines in the Great Lakes region (Klepzig et al. 1991, Miller et al. 1997). This species is typically non-aggressive, reproducing in logging slash, wind-thrown trees, and severely stressed trees (Thomas 1961). However, Ips populations may increase following the creation of an abundance of brood material (i.e., after logging or during drought stress) and subsequently infest and kill standing trees (Sartwell et al. 1971, Livingston 1979, Gara et al. 1999). In western North America, Ips has caused significant problems following harvesting, with damage to standing timber (Klepzig et al. 1991, Miller et al. 1997), and is an important killer of pole-size ponderosa pine (Pinus ponderosa Dougl. ex Laws) in the southwestern United States (Schmid 1987). In addition, high populations of Ips have been found in association with drought-stressed trees and log piles in the Algonquin region of Ontario (Howse 1995), although tree mortality was not reported.

Considerable damage and losses have also been caused by wood-boring beetle (Cerambycidae) larvae, which create large feeding tunnels throughout the wood, again causing significant reductions in the value of wood products (Richmond and Lejeune 1945, Gardiner 1957, Prebble and Gardiner 1958, Ross 1960, Gardiner 1975). Adult beetles are attracted to chemicals emitted from dead, stressed, and recently cut trees (Roden $\mathrm{et} \mathrm{al.}$ 1998). The adults lay eggs in slits cut in the bark and the larvae then create U-shaped galleries that can reach depths of $15 \mathrm{~cm}$ (Roden et al. 1998). In addition, these beetles introduce woodrotting fungi into infested trees. High populations of the whitespotted sawyer beetle [Monochamus scutellatus (Say) (Coleoptera, Cerambycidae)] associated with fire-killed stands, has caused extensive damage and economic loss (up to $30 \%$ full value) in central Saskatchewan and the Northwest Territories (Cerezke and Volney 1995). 


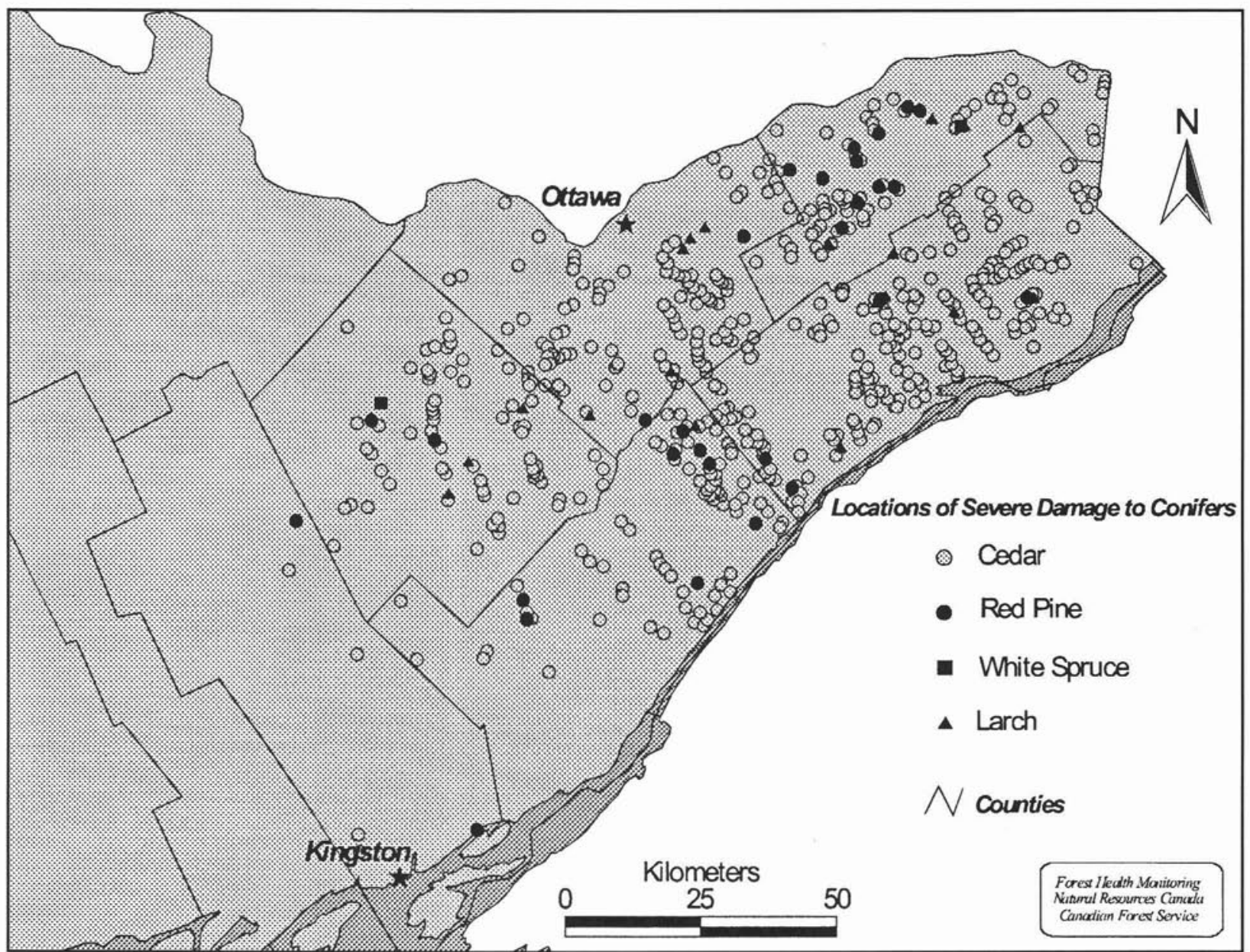

Fig. 1. Locations, recorded in 1998 during aerial survey, of severe ice damage to conifer stands. (Canadian Forest Service).

Wood-boring beetles can also cause damage when adults feed on the bark of new shoots in host conifers. Heavy damage of this type is often observed in stands adjacent to cutover areas (Howse 1995). Indeed, this feeding damage can cause tree mortality as was observed from 1977 to 1980 in northern Ontario, where 200 ha of heavy crown damage led to 135 ha of tree mortality (Howse 1995). It is well known that many species of these wood-boring beetles can increase rapidly in response to large volumes of non-resistant brood material (coarse woody debris) and the presence of stressed trees (Christiansen et al. 1987, Barry et al. 1993, Schroeder and Eidmann 1993, Schroeder et al. 1999).

\section{Ice Storm Study}

Following the 1998 ice storm, little quantified data were available upon which to base salvaging decisions regarding the likelihood of beetle outbreaks in eastern Ontario. The lack of known aggressive bark beetle species in eastern North America suggested that mortality in otherwise healthy trees was unlikely (D. Allen in Irland 1998); however, this was not known with certainty. Thus, our research was initiated to investigate the potential for bark and wood-boring beetle populations to increase in red pine plantations in those years immediately following the 1998 ice storm. Specifically, our objectives were to address: 1) changes in bark and wood-boring beetle populations in response to large volumes of woody debris; 2) the sequential pattern of infestation by these species in pine material damaged to varying degrees; and 3) the probability that additional tree mortality would be caused by these beetle infestations.

Beginning in the spring of 1998, we monitored scolytid and cerambycid populations in a number of red pine plantations with varying levels of storm damage using a variety of methods. First, surveys were conducted along forest fire fuel intersect transects in July and August (1998, 1999, 2000, and will be repeated again in 2001) to determine the total volume of woody debris, as well as the volume infested by the various beetles at each sampling date. Samples of insects infesting the woody debris were regularly collected for identification. Second, about 200 trees with varying levels of damage ( $0-75 \%$ crown loss) in different stands were tagged in 1998 and monitored yearly thereafter for mortality and evidence of insect infestation. Third, trap logs were cut and left on site in early-May $(1999,2000,2001)$ and allowed to be naturally infested by the beetles in both damaged and undamaged plantations. Trap logs were removed from these sites after 10 to 12 weeks and then placed in rearing chambers to collect and identify bark and wood-boring beetles and their natural enemies (predators and parasitoids). Finally, to further monitor populations of predators responding to changes in their scolytid prey populations, we placed Lindgren funnel traps 


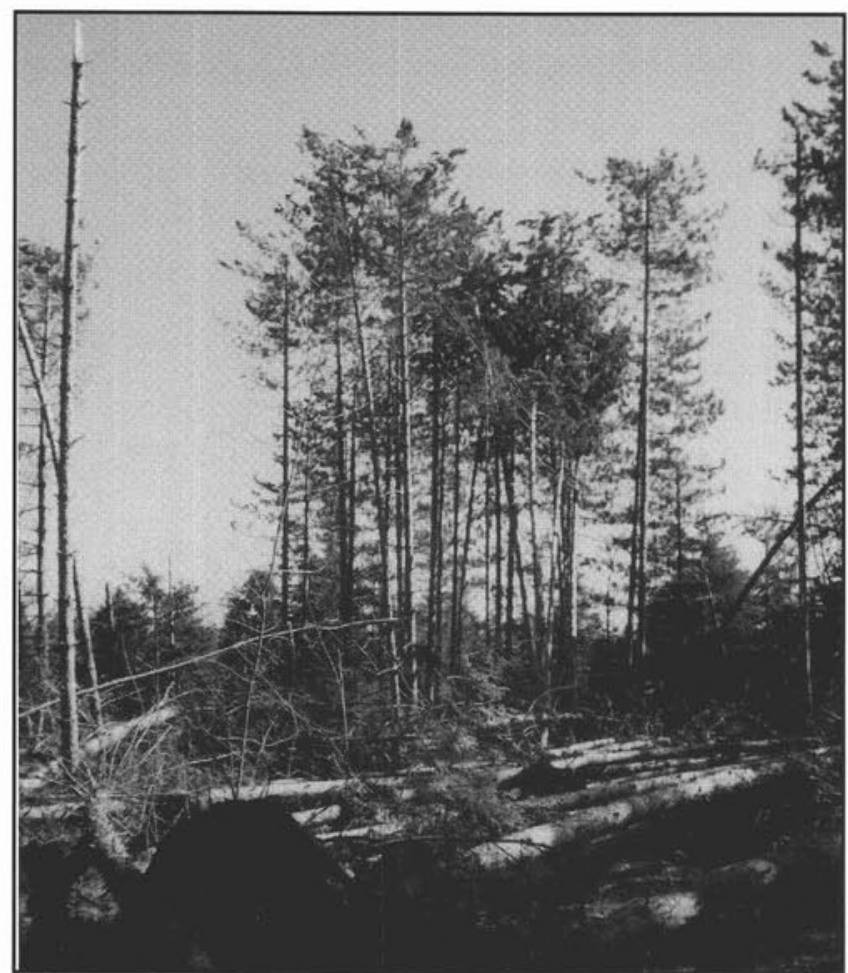

Fig. 2. Red pine uprooted and blown-down during the ice storm of 1998. (from a plantation in the Limerick Forest, Leeds and Grenville counties, southeastern Ontario.)

baited with a chemical attractive to Ips and its predators $(50+/ 50$ - ipsdienol) in both damaged and undamaged plantations during the summer of 2000 .

As expected, the two most common beetle species encountered in our monitoring were: the pine engraver beetle (Ips pini) and the white-spotted sawyer beetle (Monochamus scutellatus) (Roden et al. 1998, Thomas 1955, Gardiner 1957, Thomas 1961, Gardiner 1975). Again, both species have been reported to infest downed conifer debris and cause tree mortality (Gardiner
1957, Klepzig et al. 1991, Miller et al. 1997, Roden et al. 1998, Gara et al. 1999).

Preliminary results from the first three growing seasons following the ice storm have indicated low levels of beetlecaused tree mortality. No activity was observed in undamaged, seemingly healthy trees; however, beetles were found in standing trees with severe damage (50-75\% crown loss) (Ryall and Smith, unpublished data). In contrast, extremely high populations of both beetle species reproduced in the downed woody material (i.e., snapped tops, snags, and uprooted trees) during 1998 and 1999 (Ryall and Smith, unpublished data). To date, these results suggest that it is unlikely outbreaks of bark or woodboring beetles will kill healthy red pines in southern Ontario, although further work is needed to document their potential to stress apparently healthy trees. Detailed results from this study will be outlined in subsequent papers.

To understand why these potentially problematic bark and wood-boring beetle species did not cause the predicted tree mortality, our research expanded in 1999 and 2000 to assess the ability of natural enemies (invertebrate predators and parasitoids) to respond to and potentially suppress scolytid or cerambycid prey populations. Recent European and North American research has highlighted the potential for predators to reduce scolytid prey populations (Turchin et al. 1991, Schroeder 1996, Reeve 1997). Preliminary results from 2000 (Ryall and Smith, unpublished data) indicate a significant positive response by the predator complex that may be integral in suppressing scolytid populations and will be the subject of further work in 2001 .

\section{Conclusions}

This research was designed to improve our understanding of the population dynamics of these economically important bark and wood-boring beetle species, leading to predictions of the potential impact of these species on red pine stands with extensive accumulations of woody debris. Findings from this work will allow us to provide management recommendations to landowners regarding the likelihood of bark or wood-boring beetle infestation and tree mortality in pine plantations in the event of future ice damage or other disturbances.

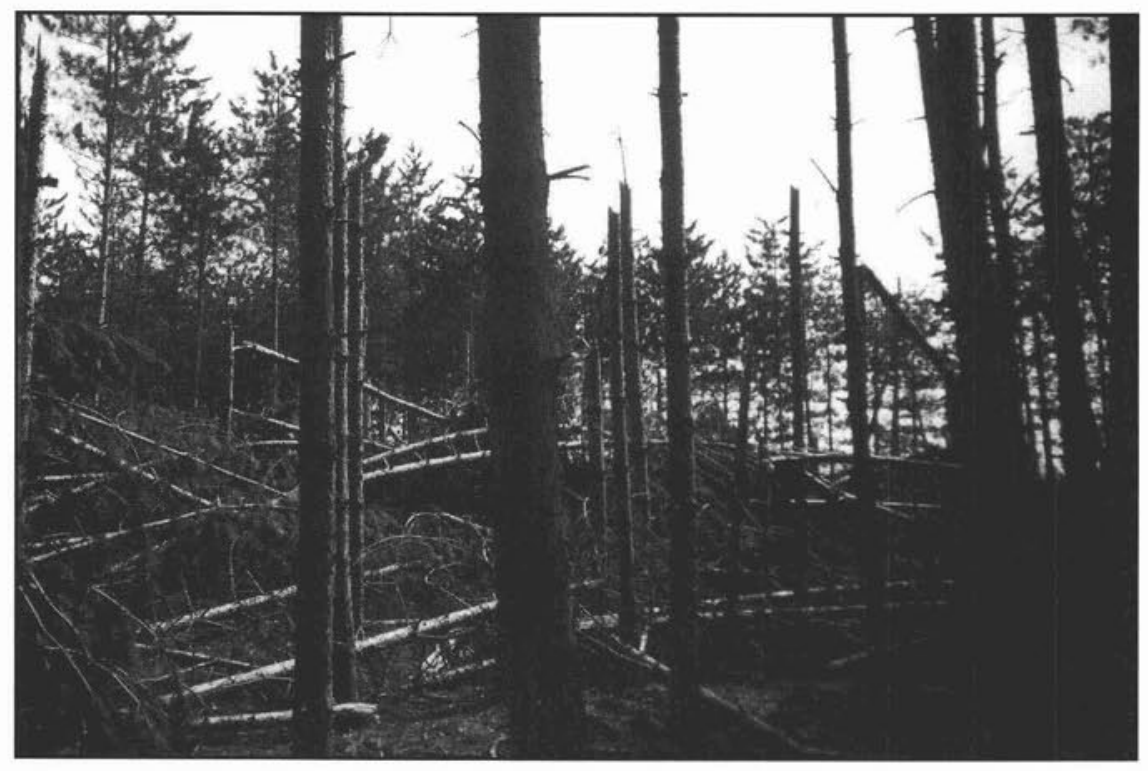

Fig. 3. Ice-storm damaged red pine showing snapped tops, standing snags, blown-down trees and undamaged trees. (from a plantation in the Limerick Forest, Leeds and Grenville counties, southeastern Ontario.) 


\section{Acknowledgements}

The authors thank the reviewers for their comments. Funding was provided by the Natural Sciences and Engineering Research Council, Canadian Forest Service (CFS) and under the Canada-Ontario Agreement for the Ice Storm Economic Recovery Assistance Program, Annex A, Assistance for the Agricultural Sector and Rural Communities in Eastern Ontario. This program was jointly funded by the Government of Canada and the Government of Ontario.

The assistance of the Ontario Ministry of Natural Resources (J. Wilson (Kemptville), R. Paquette (Kemptville), T. Scarr (Sault Ste. Marie), H. Liljalheto (Peterborough)) and CFS (G. Howse, P. deGroot, and A. Hopkin) staff was also gratefully appreciated, as well as that of summer students, L.A. Walton, C. Vance, and L. Payne.

\section{References}

Barry, P.J., C. Doggett, R.L. Anderson and K.M. Swain. 1993. How to evaluate and manage storm-damaged forest areas. United States Department of Agriculture. Forest Service Southern Region. Atlanta, GA. Management Bulletin R8-MB 63. 11 p.

Christiansen, E., R.H. Waring and A.A. Berryman. 1987. Resistance of conifers to bark beetle attack: Searching for general relationships. For. Ecol. Manag. 22(1-2): 89-106.

Cerezke, H.F. and W.J.A. Volney. 1995. Chapter 5. Forest insect pests in the Northwest region. In J.A. Armstrong and W.G.H. Ives (eds.). Forest insect pests in Canada. pp. 59-72. Natural Resources Canada. Ottawa, ON.

Gara, R.I., D.R. Millegan and K.E. Gibson. 1999. Integrated pest management of Ips pini (Col., Scolytidae) populations in southeastern Montana. J. Appl. Entomol. 123(9): 529-534.

Gardiner, L.M. 1957. Deterioration of fire-killed pine in Ontario and the causal wood-boring beetles. Can. Entomol. 89(6): 241-263.

Gardiner, L.M. 1975. Insect attack and value loss in wind-damaged spruce and jack pine stands in Northern Ontario. Can. J. For. Res. 5(3): 387-398.

Howse, G.M. 1995. Chapter 4. Forest insect pests in the Ontario region. In J.A. Armstrong and W.G.H. Ives (eds.). Forest insect pests in Canada. pp. 41-58. Natural Resources Canada. Ottawa, ON.

Irland, L.C. 1998. Ice storm 1998 and the forests of the Northeast: A preliminary assessment. J. For. 96(9): 32-40.

Klepzig, K.D., K.F. Raffa and E.B. Smalley. 1991. Association of insect-fungal complexes with red pine decline in Wisconsin. For. Sci. 37(4): 1119-1139.

Lemon, P.C. 1961. Forest ecology of ice storms. Bull. Torrey Bot. Club 88(1): 21-29.

Livingston, R.L. 1979. The pine engraver beetle in Idaho: Life history, habits, and management recommendations. Forest Insect and Disease Control Report No. 79-3. Idaho Dept. of Lands, Coeur d'Alene, ID. $7 \mathrm{p}$.

Mahaffy, F.J. 1961. The ice storm of 25-26 February 1961 at Montreal. Weatherwise 14(5): 241-244.

Miller, D.R., K.E. Gibson, K.F. Raffa, S.J. Seybold, S.A. Teale and D.L. Wood. 1997. Geographic variation in response of pine engraver, Ips pini, and associated species to pheromone, lanierone. J. Chem. Ecol. 23(8): 2013-2031.
Prebble, M.L. and L.M. Gardiner. 1958. Degrade and value loss in fire-killed pine in Mississagi area of Ontario. For. Chron. 34(2): 139-158.

Raffa, K.F. and A.A. Berryman. 1983. Physiological aspects of lodgepole pine wound responses to a fungal symbion of the mountain pine beetle. Can. Entomol. 115(7): 723-734.

Reeve, J.D. 1997. Predation and bark beetle dynamics. Oecologia 112(1): 48-54.

Richmond, H.A. and R.R. Lejeune. 1945. The deterioration of fire-killed white spruce by wood-boring insects in northern Saskatchewan. For. Chron. 21(3): 168-192.

Roden, D.B., C.N. Davis and R.N. Irwin. 1998. Common insects and pathogens infesting wind-thrown timber. Central Woodlands 2(2): 10-14.

Ross, D.A. 1960. Damage by long-horned wood borers in fire-killed white spruce, central British Columbia. For. Chron. 36(4): 355-361. Rudinsky, J.A. 1962. Ecology of Scolytidae. Ann. Rev. Entomol. 7: 327-348.

Sartwell, C., R.F. Schmitz and W.J. Buckhorn. 1971. Pine engraver, Ips pini. Forest Pest Leaflet No. 122. USDA Forest Service, Washington, D.C. 5 p.

Savage, S. 1998. The worst ice storm in Canadian history? (and) A closer look at a rare event. From: www.tor.ec.gc.ca/events/ icestorm98/icestorm98_e.html.

Schmid, J.M. 1987. Insects of ponderosa pine: impacts and control. In D.M. Baumgartner and J.E. Lotan (eds.). Ponderosa pine, the species and its management: symposium of proceedings. pp. 93-97. Washington State University, Spokane, WA.

Schroeder, L.M. 1996. Interactions between the predators Thanasimus formicarius (Col.: Cleridae) and Rhizophagus depressus (Col.: Rhizophagidae), and their bark beetle host Tomicus piniperda (Col.: Scolytidae). Entomophaga 41(1): 63-75.

Schroeder, L.M. and H.H. Eidmann. 1993. Attacks of bark- and woodboring coleoptera on snow-broken conifers over a two-year period. Scan. J. For. Res. 8(2): 257-265.

Schroeder, L.M., J. Weslien, A. Lindelöw and A. Lindhe. 1999. Attacks by bark- and wood-boring Coleoptera on mechanically created high stumps of Norway spruce in the two years following cutting. For. Ecol. Manage. 123(1): 21-30.

Stroempl, G. 1971. Gale damage in coniferous plantations in southeastern Ontario. For. Chron. 47(5): 275-278.

Thomas, J.B. 1955. Notes on insects and other arthropods in red and white pine logging slash. Can. Entomol. 87(8): 338-344.

Thomas, J.B. 1961. The life history of Ips pini (Say) (Coleoptera: Scolytidae). Can. Entomol. 93(5): 384-390.

Turchin, P., P.L. Lorio, A.D. Taylor and R.F. Billings. 1991. Why do populations of southern pine beetles (Coleoptera: Scolytidae) fluctuate? Environ. Entomol. 20(2): 401-409.

Waters, W.E., R.W.Stark and D.L. Wood (eds.). 1985. Integrated pest management in pine-bark beetle ecosystems. Wiley, New York. $256 \mathrm{p}$. 